\section{Real effective exchange rate dynamics in Morocco: Exploring Balassa-Samuelson effect under capital account liberalization}

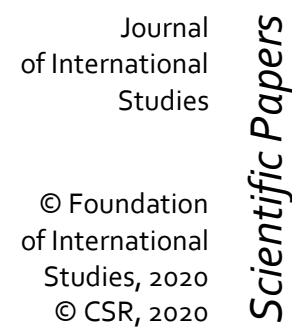

\author{
Ezzahid Elhadj \\ Mohammed V University, \\ Rabat, Morocco \\ ezzabidelhadj@gmail.com
}

Maouhoub Brahim

Mobammed V University,

Rabat, Morocco

Executive at Ministry of Economy and Finance, Morocco

b.maouboub@,live.com

Abstract. This paper discusses the sources of real effective exchange rate appreciation in Morocco as a small developing economy that opens its market to international economies. The stylized facts show a downward tendency of real effective exchange rate from 2000Q1 to 2019Q4. The question is to explain how real effective exchange rate appreciation occurs during the period of economic transition and convergence. Theoretically, we refer to the BalassaSamuelson effect according to which the real exchange rate appreciation is a result of faster relative productivities. We refer to Balassa (1964) and Samuelson (1964) and to some recent working papers in order to formulate an adequate model for Moroccan case. Our objective is to explain how domestic and foreign factors affect real effective exchange rate through the productivity gap between tradable sector and non-tradable sector. The results show that an increase in trade openness rate, in weight of US dollar in Moroccan dirham's basket currencies, in tradable production, in foreign tradable capital stock, in foreign tradable factors' output elasticity and in domestic wage level, results in real exchange rate appreciation (deterioration in external competitiveness). Meanwhile, an increase in domestic labor output elasticity, in labor force and capital transfers to tradable sector, in foreign non-tradable capital stock and in foreign non-tradable factors' output elasticity, results in real exchange rate depreciation (amelioration in external competitiveness).

Keywords: real effective exchange rate, Balassa-Samuelson effect, relative productivities, relative prices, Morocco.

JEL Classification: F31, F32
Received:

June, 2019

October, 2019

Accepted:

February, 2020

DOI:

10.14254/2071

8330.2020/13-1/24 1st Revision: 


\section{INTRODUCTION}

Morocco is a small open economy. It adopts a gradual strategy of liberalization and attaches high importance to transition to being an open economy integrated into the world markets. The liberalization policy, including capital account liberalization, begins to influence macroeconomic equilibriums and the performances of the current account, of the capital account, of the exchange market, etc. However, as in all developing countries, integration to international financial markets presents a risk relative to the real exchange rate appreciation under a fixed exchange rate regime. For this reason, liberalization requires an appropriate macroeconomic policy, institutional development and structural reforms in order to create a stable context (Pill \& Pradhan, 1997).

Moroccan monetary authorities' liberalization strategy is based on two foundations: removing all restrictions on capital inflows and maintaining partial restrictions on capital outflows. Currently, capital account is fully open for non-residents and partially open for residents, while keeping a fixed exchange rate regime. As in many developing countries, this situation refers to the desire to defend the local currency's external value and to the fear of floating (Sanusi et al., 2019). As a result, net capital inflows increase and real exchange rate appreciates. The real appreciation can be explained by the fact that an increase in capital inflows raises the demand for both tradable and non-tradable goods, and given that tradable prices are determined by the world markets, only non-tradable prices will raise. This mechanism leads to resources' transfer from non-tradable sector to tradable sector and to more real exchange appreciation through relative prices (Krumm, 1993).

The reform of exchange rate regime, under the policy of capital account liberalization, is of high importance for developing countries as it is aimed to strengthen economic competitiveness and preserve the economy from external shocks. According to Ezzahid and Maouhoub (2014) and Ezzahid and Maouhoub (2020), exchange rate flexibilization may be presented as an alternative choice to avoid real exchange rate appreciation. In this context, Moroccan monetary authorities have taken two decisions in relation to exchange rate flexibilization. Firstly, in April 2015 they altered the structure of currencies basket against which the dirham is quoted by reducing the euro weight from $80 \%$ to $60 \%$ and raising the U.S. dollar from $20 \%$ to $40 \%$. Secondly, in January 2018 they widened the dirham's fluctuations band from $0.6 \%$ either side to $2.5 \%$ either side. Recently, in March 2020, the dirham's fluctuations band is widened to $5 \%$ either side.

The experience of Latin American and South-East Asian countries shows that capital inflows were not beneficial for all developing economies and led to rapid monetary expansion, inflationary pressures, real exchange rate appreciation, financial sector difficulties, widening current account deficits, and rapid build-up of foreign debt (Khan, 1998). In view of these experiences, it is important to examine Moroccan real effective exchange rate dynamics and explain how real appreciation occurs during the period of transition. In other words, we try to construct an extended Balassa-Samuelson model to explain how faster relative productivity gains in the tradable sector with respect to non-tradable sector affect the Moroccan real effective exchange rate.

The rest of the paper is organized as follows. In section 2, we present some stylized facts and recent evolution of real effective exchange rate. In section 3, we recapitulate some empirical researches and extended models. In section 4, we construct the Balassa-Samuelson model for the Moroccan case. In section 5, we calibrate the model parameters. In section 6 , we simulate the model and we discuss the results. In the last section, we conclude with some remarks. 


\section{STYLISED FACTS AND RECENT EVOLUTION OF REAL EFFECTIVE EXCHANGE RATE}

According to Bank Al-Maghrib, the nominal effective exchange rate of the Moroccan currency (MAD) is defined as the weighted average of two international currencies: European euro (EUR) with a weight of $60 \%$ and American dollar (USD) with a weight of $40 \%$. The currencies basket of Dirham is determined based on the weights of economic partners' currencies in the whole current transactions. Thus, the European Union was the main economic partner of Morocco before 2006 and after the signature of the United States-Morocco Free Trade Agreement on June 2004 (entered into force on January 2006), Moroccan monetary authorities changed the currency basket weights on April 2015 (BAM, 2015). According to Moroccan central bank's Governor (2019) ${ }^{1}$, the aim of this reform is to absorb external shocks and boost Morocco's competitiveness.

The real effective exchange rate is defined as the deflated nominal effective exchange rate. Figure 1 represents the evolution of nominal and real effective exchange rate indexes in Morocco from 2000Q1 to 2019Q4. It shows that the nominal effective exchange rate has no tendency, whereas the real effective exchange rate has a downward tendency. This means restricted nominal adjustments -because of fixed exchange-rate regime- and real appreciations of Moroccan dirham. Figure 2 represents the scatterplot displaying values of real effective exchange rate and consumer price index during the period 2000Q12019Q4. It shows a negative link between real effective exchange rate index and consumer price index. Thus, high values of real effective exchange rate correspond to small values of the consumer price index and vice versa.

Does the real effective exchange rate appreciation reflect Moroccan economic convergence? Analyzing Figure 3 allows us to notice a negative link between relative productivities (Moroccan GDP per capita / US GDP per capita and Moroccan GDP per capita / EU GDP per capita) and real effective exchange rate. Thus, high values of real effective exchange rate correspond to small values of relative productivities between Morocco and his economic partners and vice versa. The downward trends raise questions not only about the presence of catching-up effect in developing countries but also raise concerns about future economic growth in developed countries (Maris, 2019). These remarks lead us to explore the Balassa-Samuelson effect in Morocco and to explain how economic convergence can be a source of real effective exchange rate appreciation.

\section{LITERATURE REVIEW}

The Balassa-Samuelson model, introduced by Balassa (1964) and Samuelson (1964), was deeply modified. Many versions of the model are developed based on the economic specificities of each country, that's why we find many extensions and formulations. Coudert (2004) shows how the measurement of Balassa-Samuelson effect is sensitive to the used formulations and to the implicit assumptions. The extended models are used for both developing and developed countries to examine the real exchange rate movements. We refer to the following working papers to develop an appropriate model for the Moroccan case as a small developing country.

In their working paper on the long-run behavior of the real exchange rate in six developed countries (Germany, Denmark, Norway, Sweden, UK and US), Irandoust and Sjoo (2002) develop a new model based on Froot and Rogoff $(1991,1995)$ and on Mark and Choi (1997). The authors adopt a permanenttransitory decomposition in which the real exchange rate covaries with a set of non-stationary productivity series. In order to examine the Balassa-Samuelson productivity-bias hypothesis, they test Johansen

1 Bloomberg Agency Press (2020) 
maximum likelihood and they use a vector error-correction models with yearly data from 1960 to 1995 of real exchange rates and of productivity series. The authors find a little support for the Balassa-Samuelson productivity-bias hypothesis for explaining long-run permanent shocks in the real exchange rate. Moreover, they conclude that Balassa-Samuelson effect is made to explain real exchange rate through bilateral comparison and that in a monetary union with single currency, there is no possibility of currency realignment to offset adverse output and employment effects.

Basing on the model of Dixit and Stiglitz (1977) for an open economy, Unayama (2003) constructs a Balassa-Samuelson Model for seven developed countries (Canada, France, Germany, Italy, Japan, UK and USA). The sample period is from 1975 to 1993. Introducing the concept of product variety differentiation into Balassa-Samuelson model, he find that not only relative price of non-tradable goods determines real exchange rate, but also relative price among tradable goods. Moreover, the author identifies also a new source of real exchange rate movements: which is the infrastructural technology. The improvement (deterioration) of the infrastructural technology in one country, results in a lower price levels in the other country regardless of sectors and in real exchange rate depreciation (appreciation).

Garcia-Solanes and Torrejon-Flores (2009) test the Balassa-Samuelson hypotheses for developed economies (sixteen OECD countries) and emerging economies (sixteen Latin American countries) -the USA is taken as a benchmark. Basing on the two-step procedure of Canzoneri et al. (1999), the authors split the analysis in two parts (BS1 and BS2) and applied a recent panel cointegration and bootstrapping techniques - with annual data from 1994 to 2004. The BS1 is Baumol and Bowen (1966) effect. This effect links the difference in total productivities with the difference in prices of tradable and non-tradable sectors. The BS2 establishes a relationship between the price differential and the real exchange rate. Joining the BS-1 and BS-2, the complete Balassa-Samuelson hypothesis is obtained. The authors find evidence for not rejecting the BS-1 in each group of countries. However, BS-2 is rejected only in OECD countries. The rejection is explained by two factors. The first is the speculative behavior of economic agents, generally supported by imperfect knowledge of the underlying mechanisms. The second is the non-competitive practices and arbitrage frictions that still prevail in these countries.

Using Balassa-Samuelson effect with stochastic models, Revenna and Natalucci (2008) develop a dynamic stochastic general equilibrium model for an emerging market economy based on Obstfeld and Rogoff (2000), Devereux (2001, 2003), Devereux and Lane (2006) and Gali and Monacelli (2005). The authors define the equilibrium appreciation of the real exchange rate as a result of productivity growth differentials between tradable and non-tradable sectors. They calibrate the model and compare welfare under different alternative policy rules. They find two important results. The first, the real exchange rate appreciation limits the range of policy rules that keep the inflation and the exchange rate within predetermined targets. The second, Balassa-Samuelson effect raises by an order of magnitude of the welfare loss associated with policy rules that prescribe active exchange rate management.

In their contribution to the convergence theory, Čihák and Holub (2003) develop a model integrating the Balassa-Samuelson effect with both capital accumulation model (Using the concept of tradable and non-tradable capital) and demand side of the economy. Based on empirical observation in Central and Eastern European (CEE) countries, the authors initiate a theoretical foundation of adjustment in the price level and in the relative prices. The extension of Balassa-Samuelson model provides several useful insights into the likely price adjustment process in the central European countries. Besides, the model simulations allow assessing the links between the risk premium, gross domestic product growth and real exchange appreciation, which are typically the key equilibrium variables in the macroeconomic forecasting process.

An important paper of Choudhri and Khan (2005) gives a new evidence that Balassa-Samuelson effect can explain the long-run behavior of real exchange rates in sixteen developing economies (Cameroon, Chile, Colombia, Ecuador, India, Jordan, Kenya, Korea, Malaysia, Mexico, Morocco, Philippines, South Africa, Singapore, Turkey and Venezuela), where the USA is chosen as reference. The 
authors estimate two long-run relationships using panel-data covering the period 1976-1994. The first indicates that relative prices of nontraded goods affect real exchange rate and the second indicates that labor productivity differentials between traded and nontraded goods affect relative prices. The key finding of this paper is that labor productivity's differential exerts a significant effect on the real exchange rate through its effect on nontraded goods relative prices.

\section{BALASSA-SAMUELSON METHODOLOGY AND MODEL DEVELOPMENT}

We consider two coupled economies (Figure 4): a small open developing economy (representing Morocco) and a developed economy (representing Morocco's main economic partners: European Union and United States). Each economy is subdivided into two sectors: tradable sector $T$ and non-tradable sector $N$. Tradable goods are exchanged for the price $P_{T t}$ and non-tradable goods are exchanged for the price $P_{N t}$. Tradable goods are exchanged for nominal exchange rate $E_{n t}$ which is fixed in the developing country.

The developing economy produces tradable goods and non-tradable goods using their domestic resources and foreign resources. On one hand, the domestic resources available locally are formed of domestic capital resources $K_{d t}$ and domestic labor resources $L_{d t}$. They are distributed between tradable sector $\left(K_{d T t}\right.$ and $\left.L_{d T t}\right)$ and non-tradable sector $\left(K_{d N t}\right.$ and $\left.L_{d N t}\right)$ and are remunerated at domestic interest rate $R_{t}$ and at domestic wage level $W_{t}$. On the other hand, the developed economy transfers a part of its capital resources $K_{f t}$ and of labor resources $L_{f t}$ to the developing economy. These resources are distributed between tradable sector $\left(K_{f T t}\right.$ and $\left.L_{f T t}\right)$ and non-tradable sector $\left(K_{f N t}\right.$ and $\left.L_{f N t}\right)$ and are remunerated at domestic interest rate $R_{t}$ plus risk premium $\rho_{t}$ and at foreign wage level $W_{t}^{*}$.

\subsection{Real Exchange rate and price level dynamics ${ }^{2}$}

We adopt the following definition for the real exchange rate $E_{r t}$ :

$$
E_{r t}=E_{n t} \times \frac{P_{t}^{*}}{P_{t}}
$$

$E_{n t}$ is the nominal exchange rate ${ }^{3}, P_{t}^{*}$ is the foreign price level and $P_{t}$ is the domestic price level. We define price levels as a Cobb-Douglas function as follows:

$$
\begin{aligned}
& P_{t}^{*}=P_{N t}^{*} \theta^{*} \times P_{T t}^{*}{ }^{\left(1-\theta^{*}\right)} \\
& P_{t}=P_{N t}^{\theta} \times P_{T t}^{(1-\theta)}
\end{aligned}
$$

Where $P_{N t}$ and $P_{T t}\left(P_{N t}^{*}\right.$ and $\left.P_{T t}^{*}\right)$ are respectively domestic (foreign) prices of non-tradable goods and of tradable goods, and $1-\theta\left(1-\theta^{*}\right)$ is the trade openness rate in developing (developed) country.

The geometric average foreign price level $P_{t}^{*}$ is defined as follows:

$$
P_{t}^{*}=\left(p_{N t}^{€ \theta^{\epsilon}} \times p_{T t}^{€\left(1-\theta^{€}\right)}\right)^{\zeta} \times\left(p_{N t}^{\$} \theta^{\$} \times p_{T t}^{\$}\left(1-\theta^{\$}\right)\right)^{1-\zeta}
$$

\footnotetext{
2 The superscript $(*)$ refers to the developed country.

${ }^{3} \mathrm{E}_{\mathrm{nt}}$ is defined as the price of the foreign currency in terms of the domestic one. The nominal exchange rate is normalized to 1 to indicate that the Moroccan dirham is determined by a fixed exchange rate regime.
} 
Where $1-\theta^{€}$ and $1-\theta^{\$}$ are the trade openness rates in European Union and in the Unites states, $\zeta$ and $1-\zeta$ are weights of Euro and US dollar in Moroccan dirham's basket currencies, with $0<\zeta<1$.

Thus, equation (1) becomes as follows:

$$
E_{r t}=E_{n t} \times \frac{\left(p_{N t}^{€} \theta^{\epsilon} \times p_{T t}^{€}\left(1-\theta^{€}\right)\right)^{\zeta} \times\left(p_{N t}^{\$} \theta^{\$} \times p_{T t}^{\$}\left(1-\theta^{\$}\right)\right)^{1-\zeta}}{p_{N t}^{\theta} \times p_{T t}^{(1-\theta)}}
$$

We rewrite equation (2) above in logarithmic terms and we link the relative prices to the real effective exchange rate ${ }^{4}$ as follows:

$$
e_{r t}=\left[e_{n t}+(\underbrace{\left(\zeta p_{T t}^{€}+(1-\zeta) p_{T t}^{\$}\right)}_{p_{T t}^{\ddagger}}-p_{T t})\right]-[\theta\left(p_{N t}-p_{T t}\right)-\underbrace{\left.\zeta \theta^{€}\left(p_{N t}^{€}-p_{T t}^{€}\right)-p_{T t}^{\$}\right)}_{\theta^{*}\left(p_{N t}^{\star}-p_{T t}^{\star}\right)}]
$$

The quantity $\left[e_{n t}+p_{T t}^{*}-p_{T t}\right]$ is known as the external real exchange rate and is equal to zero under purchasing power parity (PPP) assumption for tradable goods. In this case, we can write:

$$
e_{r t}=-[\theta\left(p_{N t}-p_{T t}\right)-\underbrace{\zeta \theta^{€}\left(p_{N t}^{€}-p_{T t}^{€}\right)-(1-\zeta) \theta^{\$}\left(p_{N t}^{\$}-p_{T t}^{\$}\right)}_{\theta^{*}\left(p_{N t}^{*}-p_{T t}^{*}\right)}]
$$

Under given values of $\theta, \theta^{€}$ and $\theta^{\$}$, a faster increase in domestic relative prices $\left(p_{N t}-p_{T t}\right)$ with respect to foreign relative prices $\left(p_{N t}^{*}-p_{T t}^{*}\right)$ will decrease the value of real exchange rate $e_{r t}$.

\subsection{Developing economy's structure}

We note $\mathrm{K}_{t}$ the total capital stock available in the developing economy with the following allocations:

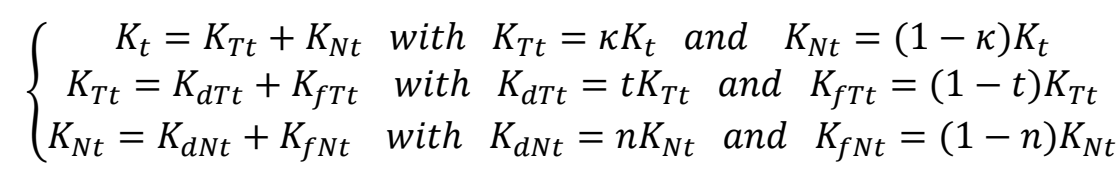

Where $0 \leq \kappa \leq 1,0 \leq t \leq 1$ and $0 \leq n \leq 1$ are coefficients of allocation.

Total capital stock in equation (5.1) is formed of capital used in tradable sector $K_{T t}$ and of capital used in non-tradable sector $K_{N t}$. In the same way, $K_{T t}$ in equation (5.2) is formed of domestic capital $K_{d T t}$ and of foreign capital $K_{f T t}$ used in tradable sector, and $K_{N t}$ in equation (5.3) is formed of domestic capital $K_{d N t}$ and of foreign capital $K_{f N t}$ used in non-tradable sector.

Similarly, we note $L_{t}$ the total labor force employed in the developing economy with the following allocations:

$$
\left\{\begin{array}{c}
L_{t}=L_{T t}+L_{N t} \text { with } L_{T t}=l L_{t} \text { and } L_{N t}=(1-l) L_{t} \\
L_{T t}=L_{d T t}+L_{f T t} \text { with } L_{d T t}=s L_{T t} \text { and } L_{f T t}=(1-s) L_{T t} \\
L_{N t}=L_{d N t}+L_{f N t} \text { with } L_{d N t}=m L_{N t} \text { and } L_{f N t}=(1-m) L_{N t}
\end{array}\right.
$$

Where $0 \leq l \leq 1,0 \leq s \leq 1$ and $0 \leq m \leq 1$ are coefficients of allocation.

\footnotetext{
${ }^{4} \mathrm{~A}$ decrease (an increase) in $\mathrm{E}_{\mathrm{rt}}$ means a real appreciation (real depreciation) of the domestic currency.
} 
Total labor force in equation (6.1) is formed of labor force employed in tradable sector $L_{T t}$ and of labor force employed in non-tradable sector $L_{N t}$. In the same way, $L_{T t}$ in equation (6.2) is formed of domestic labor force $L_{d T t}$ and of foreign labor force $L_{f T t}$ employed in tradable sector, and $L_{N t}$ in equation (6.3) is formed of domestic labor force $L_{d N t}$ and of foreign labor force $L_{f N t}$ employed in nontradable sector. We adopt the following Cobb-Douglas function concerning the production process of $\Upsilon_{t}$ :

$$
\left\{\begin{array}{c}
\Upsilon_{t}=A_{t} \cdot L_{t}^{\eta} \cdot K_{t}^{1-\eta} \\
\Upsilon_{T t}=\epsilon \Upsilon_{t} \text { and } \Upsilon_{N t}=(1-\epsilon) Y_{t}
\end{array}\right.
$$

\section{With $0 \leq \epsilon \leq 1$}

Where $A_{t}$ is the domestic total factors productivity, $\eta$ is the output elasticity of labor, $1-\eta$ is the output elasticity of capital, $\epsilon$ is the share of tradable production $Y_{T t}$ in the total production $Y_{t}$, and (1$\epsilon$ ) is the share of non-tradable production $Y_{N t}$ in the total production $Y_{t}$. From equations (5.1), (6.1) and (7.2), we obtain the desegregation of total production function(7.1) into tradable production function (8.1) and non-tradable production function (8.2) as follows:

$$
\left\{\begin{array}{c}
\Upsilon_{T t}=\left[\frac{\epsilon}{l^{\eta} \cdot \kappa^{1-\eta}} \cdot A_{t}\right] \cdot L_{T t}^{\eta} \cdot K_{T t}^{1-\eta} \\
\Upsilon_{N t}=\left[\frac{1-\epsilon}{(1-l)^{\eta} \cdot(1-\kappa)^{1-\eta}} \cdot A_{t}\right] \cdot L_{N t}^{\eta} \cdot K_{N t}^{1-\eta}
\end{array}\right.
$$

From equations (5.2) and (6.2), we obtain two expressions of tradable production (8.1) in function of domestic resources (9.1) and of foreign resources (9.2) as follows:

$$
\left\{\begin{array}{c}
\Upsilon_{T t}=\left[\frac{\epsilon}{l \eta} \cdot \kappa^{1-\eta} \cdot \frac{1}{s^{\eta} \cdot t^{1-\eta}} \cdot A_{t}\right] \cdot L_{d T t}^{\eta} \cdot K_{d T t}^{1-\eta} \\
\Upsilon_{T t}=\left[\frac{\epsilon}{l \eta \cdot \kappa^{1-\eta}} \cdot \frac{1}{(1-s)^{\eta} \cdot(1-t)^{1-\eta}} \cdot A_{t}\right] \cdot L_{f T t}^{\eta} \cdot K_{f T t}^{1-\eta}
\end{array}\right.
$$

We can simply write equations (9.1) and (9.2) as follows:

$$
\Upsilon_{T t}=\Upsilon_{T t}^{\alpha} \cdot \Upsilon_{T t}^{1-\alpha}, \text { with } 0 \leq \alpha \leq 1
$$

Using equations (9.1), (9.2) and (10), we can write the tradable production function as follows:

$$
\left\{\begin{array}{c}
\Upsilon_{T t}=A_{T t} \cdot L_{d T t}^{\alpha \eta} \cdot L_{f T t}^{(1-\alpha) \eta} \cdot K_{d T t}^{\alpha(1-\eta)} \cdot K_{f T t}^{(1-\alpha)(1-\eta)} \\
A_{T t}=\frac{\epsilon}{l^{\eta} \cdot \kappa^{1-\eta} \cdot s^{\alpha \eta} \cdot(1-s)^{(1-\alpha) \eta} \cdot t^{\alpha(1-\eta)} \cdot(1-t)^{(1-\alpha)(1-\eta)} \cdot A_{t}}
\end{array}\right.
$$

Where $\alpha \eta$ is the output elasticity of domestic labor employed in tradable sector, $(1-\alpha) \eta$ is the output elasticity of foreign labor force employed in tradable sector, $\alpha(1-\eta)$ is the output elasticity of domestic capital used in tradable sector and $(1-\alpha)(1-\eta)$ is the output elasticity of foreign capital used in tradable sector. From equations (5.3) and (6.3), we obtain two expressions of non-tradable production (8.2) in function of domestic resources (12.1) and of foreign resources (12.2) as follows: 


$$
\left\{\begin{array}{c}
\Upsilon_{N t}=\left[\frac{1-\epsilon}{(1-l)^{\eta} \cdot(1-\kappa)^{1-\eta}} \cdot \frac{1}{m^{\eta} \cdot n^{1-\eta}} \cdot A_{t}\right] \cdot L_{d N t}^{\eta} \cdot K_{d N t}^{1-\eta} \\
\Upsilon_{N t}=\left[\frac{1-\epsilon}{(1-l)^{\eta} \cdot(1-\kappa)^{1-\eta}} \cdot \frac{1}{(1-m)^{\eta} \cdot(1-n)^{1-\eta}} \cdot A_{t}\right] \cdot L_{f N t}^{\eta} \cdot K_{f N t}^{1-\eta}
\end{array}\right.
$$

We can also simply write equations (12.1) and (12.2) as follows:

$$
\Upsilon_{N t}=\Upsilon_{N t}^{\beta} \cdot \Upsilon_{N t}^{1-\beta} \text {, with } 0 \leq \beta \leq 1
$$

Using equations (12.1), (12.2) and (13), we can write the non-tradable production function as follows:

$$
\left\{\begin{array}{c}
\Upsilon_{N t}=A_{N t} \cdot L_{d N t}^{\beta \eta} \cdot L_{f N t}^{(1-\beta) \eta} \cdot K_{d N t}^{\beta(1-\eta)} \cdot K_{f N t}^{(1-\beta)(1-\eta)} \\
A_{N t}=\frac{1-\epsilon}{(1-l)^{\eta} \cdot(1-\kappa)^{1-\eta} \cdot m^{\beta \eta} \cdot(1-m)^{(1-\beta) \eta} \cdot n^{\beta(1-\eta)} \cdot(1-n)^{(1-\beta)(1-\eta)}} A_{t}
\end{array}\right.
$$

Where $\beta \eta$ is the output elasticity of domestic labor force employed in non-tradable sector, $(1-\beta) \eta$ is the output elasticity of foreign labor force employed in non-tradable sector, $\beta(1-\eta)$ is the output elasticity of domestic capital used in non-tradable sector and $(1-\beta)(1-\eta)$ is the output elasticity of foreign capital used in non-tradable sector.

We adopt the following assumptions for the developing economy's sectors:

\section{Assumption 1: imperfect inter-economies labor force mobility.}

It implies that in the developing economy, domestic labor force is remunerated at a domestic wage level $W_{t}$ whereas foreign labor force is remunerated at a foreign wage level $W^{*}$. In contrary in developed country, all labor force -domestic and foreign- is remunerated at the same wage level $W^{*}$. As a result, marginal product of foreign labor force in developing economy is higher than marginal product of domestic labor force $W^{*}>W$. This indicates that foreign labor is more skilled than domestic labor.

\section{Assumption 2: perfect inter-sectors labor force mobility.}

This assumption implies that marginal product of domestic labor employed in tradable sector is equal to the marginal product of domestic labor employed in non-tradable sector (15), and that marginal product of foreign labor in tradable sector is equal to the marginal product of foreign labor in nontradable sector (16):

$$
\begin{aligned}
& P_{T t} \cdot \frac{\partial \Upsilon_{T t}}{\partial L_{d T t}}=P_{N t} \cdot \frac{\partial \Upsilon_{N t}}{\partial L_{d N t}}=W \\
& P_{T t} \cdot \frac{\partial \Upsilon_{T t}}{\partial L_{f T t}}=P_{N t} \cdot \frac{\partial \Upsilon_{N t}}{\partial L_{f N t}}=W^{*}
\end{aligned}
$$

This is equivalent to:

$$
\begin{array}{r}
\alpha \eta \cdot P_{T t} \cdot A_{T t} \cdot L_{d T t}^{\alpha \eta-1} \cdot L_{f T t}^{(1-\alpha) \eta} \cdot K_{d T t}^{\alpha(1-\eta)} \cdot K_{f T t}^{(1-\alpha)(1-\eta)}= \\
\beta \eta \cdot P_{N t} \cdot A_{N t} \cdot L_{d N t}^{\beta \eta-1} \cdot L_{f N t}^{(1-\beta) \eta} \cdot K_{d N t}^{\beta(1-\eta)} \cdot K_{f N t}^{(1-\beta)(1-\eta)} \\
(1-\alpha) \eta \cdot P_{T t} \cdot A_{T t} \cdot L_{d T t}^{\alpha \eta} \cdot L_{f T t}^{(1-\alpha) \eta-1} \cdot K_{d T t}^{\alpha(1-\eta)} \cdot K_{f T t}^{(1-\alpha)(1-\eta)}=(1-1) \\
\beta) \eta \cdot P_{N t} \cdot A_{N t} \cdot L_{d N t}^{\beta \eta} \cdot L_{f N t}^{(1-\beta) \eta-1} \cdot K_{d N t}^{\beta(1-\eta)} \cdot K_{f N t}^{(1-\beta)(1-\eta)}
\end{array}
$$




\section{Assumption 3: imperfect inter-economies capital mobility}

In the developing economy, domestic capital is remunerated at domestic interest rate $R$ and foreign capital is remunerated at domestic interest rate level plus risk premium $R+\rho$. In contrary of what is observed in developed country, capital is remunerated at foreign interest rate $R_{t}^{*}$. As a result, marginal product of foreign capital in the developing economy is higher than marginal product of domestic capital $R+\rho>R$.

\section{Assumption 4: perfect inter-sectors capital mobility}

This implies that the marginal product of domestic capital in tradable sector is equal to the marginal product of domestic capital in non-tradable sector (17) and that marginal product of foreign capital in tradable sector is equal to the marginal product of foreign capital in non-tradable sector (18):

$$
\begin{aligned}
P_{T t} \cdot \frac{\partial \Upsilon_{T t}}{\partial K_{d T t}} & =P_{N t} \cdot \frac{\partial \Upsilon_{N t}}{\partial K_{d N t}}=R \\
P_{T t} \cdot \frac{\partial \Upsilon_{T t}}{\partial K_{f T t}} & =P_{N t} \cdot \frac{\partial \Upsilon_{N t}}{\partial K_{f N t}}=R+\rho
\end{aligned}
$$

This is equivalent to:

$$
\begin{array}{r}
\alpha(1-\eta) \cdot P_{T t} \cdot A_{T t} \cdot L_{d T t}^{\alpha \eta} \cdot L_{f T t}^{(1-\alpha) \eta} \cdot K_{d T t}^{\alpha(1-\eta)-1} \cdot K_{f T t}^{(1-\alpha)(1-\eta)}=\beta(1- \\
\eta) \cdot P_{N t} \cdot A_{N t} \cdot L_{d N t}^{\beta \eta} \cdot L_{f N t}^{(1-\beta) \eta} \cdot K_{d N t}^{\beta(1-\eta)-1} \cdot K_{f N t}^{(1-\beta)(1-\eta)} \\
(1-\alpha)(1-\eta) \cdot P_{T t} \cdot A_{T t} \cdot L_{d T t}^{\alpha \eta} \cdot L_{f T t}^{(1-\alpha) \eta} \cdot K_{d T t}^{\alpha(1-\eta)} \cdot K_{f T t}^{(1-\alpha)(1-\eta)-1}= \\
(1-\beta)(1-\eta) \cdot P_{N t} \cdot A_{N t} \cdot L_{d N t}^{\beta \eta} \cdot L_{f N t}^{(1-\beta) \eta} \cdot K_{d N t}^{\beta(1-\eta)} \cdot K_{f N t}^{(1-\beta)(1-\eta)-1}
\end{array}
$$

For tradable sector, we obtain equations (19)-(22) from equations (15.1), (16.1), (17.1) and (18.1):

$$
\left\{\begin{array}{l}
\frac{L_{f T t}}{L_{d T t}}=\frac{1-\alpha}{\alpha} \cdot \frac{W}{W^{*}} \\
\frac{K_{f T t}}{K_{d T t}}=\frac{1-\alpha}{\alpha} \cdot \frac{R}{R+\rho} \\
\frac{K_{d T t}}{L_{d T t}}=\frac{(1-\eta)}{\eta} \cdot \frac{W}{R} \\
\frac{K_{f T t}}{L_{f T t}}=\frac{(1-\eta)}{\eta} \cdot \frac{W^{*}}{R+\rho}
\end{array}\right.
$$

Replacing equations (19)-(22) in the left-hand side of equation (15.1) gives the tradable goods price in the developing country as follows:

$$
P_{T t}=\frac{1}{\alpha^{\alpha} \eta^{\eta}(1-\alpha)^{(1-\alpha)}(1-\eta)^{(1-\eta)} A_{T t}} \cdot W^{*(1-\alpha) \eta} \cdot W^{\alpha \eta} \cdot R^{\alpha(1-\eta)} \cdot(R+\rho)^{(1-\alpha)(1-\eta)}
$$

For non-tradable sector, we obtain the equations (24)-(27) from equations (15.1), (16.1), (17.1) and (18.1): 


$$
\left\{\begin{array}{c}
\frac{L_{f N t}}{L_{d N t}}=\frac{1-\beta}{\beta} \cdot \frac{W}{W^{*}} \\
\frac{K_{f N t}}{K_{d N t}}=\frac{1-\beta}{\beta} \cdot \frac{R}{R+\rho} \\
\frac{K_{d N t}}{L_{d N t}}=\frac{(1-\eta)}{\eta} \cdot \frac{W}{R} \\
\frac{K_{f N t}}{L_{f N t}}=\frac{(1-\eta)}{\eta} \cdot \frac{W^{*}}{R+\rho}
\end{array}\right.
$$

Replacing equations (24)-(27) in the right-hand side of equation (15.1) gives the non-tradable goods price in the developing country:

$$
P_{N t}=\frac{1}{\beta^{\beta} \eta^{\eta}(1-\beta)^{(1-\beta)}(1-\eta)^{(1-\eta)} A_{N t}} \cdot W^{*(1-\beta) \eta} \cdot W^{\beta \eta} \cdot R^{\beta(1-\eta)} \cdot(R+\rho)^{(1-\beta)(1-\eta)}
$$

Dividing equation (28) by equation (23) gives the relative prices in developing country:

$$
\frac{P_{N t}}{P_{T t}}=\frac{\alpha^{\alpha} \cdot(1-\alpha)^{(1-\alpha)}}{\beta^{\beta} \cdot(1-\beta)^{(1-\beta)}} \cdot \frac{A_{T t}}{A_{N t}} \cdot\left(\frac{W^{*}}{W}\right)^{(\alpha-\beta) \eta} \cdot\left(\frac{R+\rho}{R}\right)^{(\alpha-\beta)(1-\eta)}
$$

Dividing equation (11.2) by equation (14.2) gives the relative total factors productivities in the economy:

$$
\frac{A_{T t}}{A_{N t}}=\frac{\epsilon \cdot(1-l)^{\eta} \cdot(1-\kappa)^{1-\eta} \cdot m^{\beta \eta} \cdot n^{\beta(1-\eta)} \cdot(1-m)^{(1-\beta) \eta} \cdot(1-n)^{(1-\beta)(1-\eta)}}{(1-\epsilon) \cdot l^{\eta} \cdot \kappa^{1-\eta} \cdot s^{\alpha \eta} \cdot t^{\alpha(1-\eta)} \cdot(1-s)^{(1-\alpha) \eta} \cdot(1-t)^{(1-\alpha)(1-\eta)}}
$$

We notice that when $\alpha=\beta$ (i.e. when the output elasticity of domestic labor employed in tradable sector is equal to the output elasticity of domestic labor employed in non-tradable sector, the output elasticity of foreign labor employed in tradable sector is equal to the output elasticity of foreign labor employed in non-tradable sector, the output elasticity of domestic capital used in tradable sector is equal to the output elasticity of domestic capital used in non-tradable sector, and the output elasticity of foreign capital used in tradable sector is equal to the output elasticity of foreign capital used in non-tradable sector), relative prices corresponds to relative total factor productivities:

$$
\frac{P_{N t}}{P_{T t}}=\frac{A_{T t}}{A_{N t}}
$$

\subsection{Developed economy's structure}

We note $K_{t}^{*}$ the total capital stock available in developed economy with the following allocation:

$$
K_{t}^{*}=K_{T t}^{*}+K_{N t}^{*} \text { with } K_{T t}^{*}=\kappa^{*} K_{t}^{*} \text { and } K_{N t}^{*}=\left(1-\kappa^{*}\right) K_{t}^{*}
$$

Where $0 \leq \kappa^{*} \leq 1$ is a coefficient of allocation. Total capital stock in equation (32) is formed of capital used in tradable sector $K_{T t}^{*}$ and of capital used in non-tradable sector $K_{N t}^{*}$. Similarly, we note $L_{t}^{*}$ the total labor force employed in the developed economy with the following allocation:

$$
L_{t}^{*}=L_{T t}^{*}+L_{N t}^{*} \text { with } L_{T t}^{*}=l^{*} L_{t}^{*} \text { and } L_{N t}^{*}=\left(1-l^{*}\right) L_{t}^{*}
$$

Where $0 \leq l^{*} \leq 1$ is a coefficient of allocation. Total labor force in equation (33) is formed of labor force employed in tradable sector $L_{T t}^{*}$ and of labor force employed in non-tradable sector $L_{N t}^{*}$. We adopt the following Cobb-Douglas production function for the developed economy's production process of $Y_{t}^{*}$ : 


$$
\begin{aligned}
& \left\{\begin{array}{c}
Y_{t}^{*}=A_{t}^{*} \cdot L_{t}^{* \eta^{*}} \cdot K_{t}^{* 1-\eta^{*}} \\
Y_{T t}^{*}=\epsilon^{*} Y_{t}^{*} \text { and } Y_{T t}^{*}=\left(1-\epsilon^{*}\right) Y_{t}^{*}
\end{array}\right. \\
& \text { with } 0 \leq \epsilon^{*} \leq 1
\end{aligned}
$$

Where $A_{t}^{*}$ is the total factors productivity in developed economy, $\eta^{*}$ is the output elasticity of labor, $1-\eta^{*}$ is the output elasticity of capital, $\epsilon^{*}$ is the share of tradable production $Y_{T t}^{*}$ on total production and $\left(1-\epsilon^{*}\right)$ is the share of non-tradable production $Y_{N t}^{*}$ on total production. From equations (32), (33) and (34.2), we obtain the desegregation of total production function (34.1) into tradable production function (35.1) and non-tradable production function (35.2) as follows:

$$
\left\{\begin{array}{l}
Y_{T t}^{*}=A_{T t}^{*} \cdot L_{T t}^{* \eta^{*}} \cdot K_{T t}^{* 1-\eta^{*}} \\
Y_{N t}^{*}=A_{N t}^{*} \cdot L_{N t}^{* \eta^{*}} \cdot K_{N t}^{* 1-\eta^{*}}
\end{array}\right.
$$

With the following definitions of sectorial total factor productivities:

$$
\left\{\begin{array}{c}
A_{T t}^{*}=\left[\frac{\epsilon^{*}}{l^{*} \eta \cdot \kappa^{* 1-\eta^{*}}} \cdot A_{t}^{*}\right] \\
A_{N t}^{*}=\left[\frac{1-\epsilon^{*}}{\left(1-l^{*}\right)^{\eta^{*}} \cdot\left(1-\kappa^{*}\right)^{1-\eta^{*}}} \cdot A_{t}^{*}\right]
\end{array}\right.
$$

We adopt the following assumptions for the developed economy's sectors:

\section{Assumption 5: perfect inter-sectors labor force mobility}

All labor force is remunerated at the same wage level $W^{*}$. This assumption implies that the marginal product of labor in tradable sector is equal to the marginal product of labor in non-tradable sector:

$$
P_{T t}^{*} \cdot \frac{\partial \Upsilon_{T t}^{*}}{\partial L_{T t}^{*}}=P_{N t}^{*} \cdot \frac{\partial \Upsilon_{N t}^{*}}{\partial L_{N t}^{*}}=W^{*}
$$

This is equivalent to:

$$
\begin{aligned}
& \eta^{*} P_{T t}^{*} \cdot A_{T t}^{*} \cdot L_{T t}^{\left(\eta^{*}-1\right)} \cdot K_{T t}^{\left(1-\eta^{*}\right)}=W^{*} \\
& \eta^{*} P_{N t}^{*} \cdot A_{N t}^{*} \cdot L_{N t}^{\left(\eta^{*}-1\right)} \cdot K_{N t}^{\left(1-\eta^{*}\right)}=W^{*}
\end{aligned}
$$

\section{Assumption 6: perfect inter-sectors capital mobility}

In developed economy, capital is remunerated at the market interest rate $R^{*}$. The assumption means that the marginal product of capital in tradable sector is equal to the marginal product of capital in nontradable sector:

$$
P_{T t}^{*} \cdot \frac{\partial \Upsilon_{T t}^{*}}{\partial K_{T t}^{*}}=P_{N t}^{*} \cdot \frac{\partial \Upsilon_{N t}^{*}}{\partial K_{N t}^{*}}=R^{*}
$$

This is equivalent to:

$$
\begin{aligned}
& \left(1-\eta^{*}\right) P_{T t}^{*} \cdot A_{T t}^{*} \cdot L_{T t}^{* \eta^{*}} \cdot K_{T t}^{*\left(-\eta^{*}\right)}=R^{*} \\
& \left(1-\eta^{*}\right) P_{N t}^{*} \cdot A_{N t}^{*} \cdot L_{N t}^{* \eta^{*}} \cdot K_{N t}^{*\left(-\eta^{*}\right)}=R^{*}
\end{aligned}
$$

From equations (39)-(42), we obtain the expression of relative factors (43) and (44) as follows: 


$$
\left\{\begin{array}{l}
\frac{K_{T t}^{*}}{L_{T t}^{*}}=\frac{\left(1-\eta^{*}\right)}{\eta^{*}} \cdot \frac{W^{*}}{R^{*}} \\
\frac{K_{N t}^{*}}{L_{N t}^{*}}=\frac{\left(1-\eta^{*}\right)}{\eta^{*}} \cdot \frac{W^{*}}{R^{*}}
\end{array}\right.
$$

From equations (38)-(44), we obtain the equilibrium values of relative prices as follows:

$$
\frac{P_{N t}^{*}}{P_{T t}^{*}}=\frac{A_{T t}^{*}}{A_{N t}^{*}}
$$

We can write from (36.1) and (36.2) the relative sectorial total factor productivities as follows:

$$
\frac{A_{T t}^{*}}{A_{N t}^{*}}=\frac{\epsilon^{*}\left(1-\epsilon^{*}\right)}{l^{*} \eta^{*} .\left(1-l^{*}\right)^{\eta^{*}} \cdot \kappa^{* 1-\eta^{*}} .\left(1-\kappa^{*}\right)^{1-\eta^{*}}}
$$

We substitute the expressions of relative total factor productivities (30) and (46) in equations (29) and (45) and then we substitute (with logarithms) the expressions of relative prices (29) and (30) in equation (4). The developed Balassa-Samuelson model would allow us to quantify and analyze the real effective exchange rate dynamics in Morocco. However, the extended model has three limitations. First, it is a static model where the variation of the different parameters only affects the equilibrium values, which does not allow a dynamic analysis of real effective exchange rate and of capital account liberalization. Second, the model is based on the assumptions of the production factors' perfect intra-economy mobility, which are not empirically verified. Third, the model parameters' calibration is questionable. Some parameters are estimated from different years and others are estimated through approximate calculations.

\section{MODEL PARAMETERS' CALIBRATION}

Based on Moroccan, the European Union and the United-states economic conditions, we select the following values to calibrate the model parameters and then we change the developing country parameters to simulate their effect on real exchange rate.

\section{Trade openness rates $\mathbf{1}-\boldsymbol{\theta}, \mathbf{1}-\boldsymbol{\theta}^{€}$ and $\mathbf{1}-\boldsymbol{\theta}^{\$}$}

The trade openness rate is measured by the ratio of total exports and imports on gross domestic product. Based on the last available data in 2017, the trade openness rates is calculated as Table 1 shows. We have: $1-\theta=80.80 \%, 1-\theta^{€}=88.25 \%$, and $1-\theta^{\$}=26.98 \%$.

\section{Labor output elasticities $\left(\boldsymbol{\eta}, \boldsymbol{\eta}^{€}\right.$ and $\left.\boldsymbol{\eta}^{\$}\right)$}

We use the values presented in Table 2 for labor output elasticities. These values are selected from the available studies on Morocco, the European Union and the Unites-States: $\eta=0.60, \eta^{€}=0.63$ and $\eta^{\$}=0.70$.

\section{Weights of Euro and US dollar in Moroccan dirham's quoting basket currencies $\zeta$ and $1-\zeta$}

We refer to the weights of Moroccan dirham's quoting basket currencies: European euro (EUR) with a weight of $60 \%$ and the American dollar (USD) with a weight of $40 \%$. 


\section{The developing economy's wage level $\boldsymbol{W}$ and developed country's wage level $\boldsymbol{W}^{*}$}

We refer to the adjusted net national income per capita representing the average wage as indicated in the World Bank Dataset. The recent data available is in 2015 and is presented in Table 3. We select $\mathrm{W}=$ $2,503.58$ US $\$$ for domestic wage level and $W^{*}=W^{€ \zeta} \times W^{\$^{1-\zeta}}=33,917.12$ US $\$$ for foreign wage level.

\section{Domestic country's interest rate $\boldsymbol{R}$ and risk premium $\boldsymbol{\rho}$}

According to the World Bank Database, the Moroccan deposit interest rate in 2017 was $R=$ $3.1225 \%$. For risk premium in Morocco, we select the country risk premium calculated ${ }^{5}$ by Damodaran (2016) which is $\rho=2.88 \%$.

\section{Coefficients of allocation $l, \kappa$ and $\epsilon\left(l^{*}, \kappa^{*}\right.$ and $\left.\epsilon^{*}\right)$}

We adopt the criteria and ratios in Table 4 for distinguishing between tradable sector and nontradable sector and for calculating the coefficients of allocation. We use the same criteria and ratios to calculate $l^{*}, \kappa^{*}$ and $\epsilon^{*}$. The estimated coefficients are summarized in Table 5. Given the available data, the graphic representation of $\kappa, \kappa^{€}, \kappa^{\$}, \epsilon, \epsilon^{\$}$ and $\epsilon^{\$}$ are represented in Figures 5 and 6.

\section{Coefficients $t, \alpha, \mathrm{s}, \boldsymbol{n}, \boldsymbol{\beta}$ and $m$}

Considering the absence of data on foreign capital allocation between tradable and non-tradable sectors, we use the criteria presented in Table 6 . As a result, the coefficients $t$ and $n$ are calculated in Table 7 as follows: $t=0.9520$ and $n=0.9612$. As in many developing and emerging markets, these values confirms the low internationalization of domestic firms -see for example Strýčková (2017)- due to the limitations on foreign capital participation. From equations (5.2), (5.3), (20), and (25), we obtain:

$$
\left\{\begin{array}{l}
\alpha=\frac{t}{t+(1-t) \cdot \frac{R+\rho}{R}} \\
\beta=\frac{n}{n+(1-n) \cdot \frac{R+\rho}{R}}
\end{array}\right.
$$

The values of parameters $\alpha$ and $\beta$ are simply computed by using equation (47) and (48) and replacing $t, R, \rho$ and $n$ by their values above given : $\alpha=0.9116$ and $\beta=0.9279$. Similarly, from equations (6.2), (6.3), (19), and (24), we deduce the following expressions:

$$
\left\{\begin{array}{l}
s=\frac{1}{1+\frac{1-\alpha}{\alpha} \cdot \frac{W}{W^{*}}} \\
m=\frac{n}{1+\frac{1-\beta}{\beta} \cdot \frac{W}{W^{*}}}
\end{array}\right.
$$

Finally, the values of parameters $S$ and $m$ are estimated as follows: $s=0.9928$ and $m=0.9943$.

\footnotetext{
${ }^{5}$ For more details see www.pages.stern.nyu.edu/ adamodar/New_Home_Page/datafile/ctryprem.html
} 


\section{EMPIRICAL RESULTS AND DISCUSSION}

The computation of the real exchange rate (eq. 4) gives the following value for a single year: $e_{r}=$ 0.0616 or $E_{r}=\exp \left(e_{r}\right)=1.0635$. Thus, we analyze the effect of parameters variation as follows: any decrease of $E_{r}$ is viewed as a real appreciation and any increase of its value is viewed as a real depreciation.

\section{Trade openness rate $1-\boldsymbol{\theta}$}

We notice that an increase of trade openness rate (Figure 7) -the increase of trade with the rest of the world- reduces the real exchange rate (real appreciation). The increase of imports and exports raises the tradable prices with respect to non-tradable prices, which raises the domestic inflation with respect to the foreign inflation and then decreases the exchange rate in real terms. This mechanism can be assimilated to the exchange rate pass-through according to which a change in the price of imported goods and services affects the price of domestic goods and services.

\section{Production factors' output elasticity $\boldsymbol{\eta}$}

Increasing $\eta$-improvement of labor force efficiency with respect to physical capital stock- results in a minor real exchange rate depreciation (Figure 8). The depreciation is due to the allocation of labor force and capital stock $(l>\kappa)$ between tradable sector and non-tradable sector. When the coefficients of allocation are equal $(l=\kappa)$ increasing $\eta$ doesn't affect real exchange rate.

\section{Weight of foreign currencies $\zeta$}

Decreasing $\zeta$ (reducing the weight of Euro in favor of US Dollar) results in a real exchange rate appreciation (Figure 9), because the productivity gap between Morocco and USA is higher than the productivity gap between Morocco and EU (see Figure 3). This means that US relative prices $\left(p_{N t}^{\$}-p_{T t}^{\$}\right)$ are higher than EU relative price $\left(p_{N t}^{€}-p_{T t}^{€}\right)$ and that decreasing $\zeta$ raises the gap between Moroccan relative prices $\left(p_{N t}-p_{T t}\right)$ and foreign relative prices $\left(p_{N t}^{*}-p_{T t}^{*}\right)$, which appreciates the real exchange rate.

\section{Coefficients of allocation $l, \kappa$ and $\epsilon$}

The transfer of labor force (Figure 10) or capital (Figure 11) from non-tradable sector to tradable sector - under unchanged production of tradables and non-tradables- results in a real exchange rate depreciation. Moreover, real depreciation resulting from labor force transfers is higher than real depreciation resulting from capital transfers, because of high labor output elasticity $\eta$ compared to capital stock output elasticity $1-\eta$. The production factors transfer decreases the productivity in tradable sector with respect to non-tradable sector, which decreases domestic relative prices $\left(p_{N t}-p_{T t}\right)$ with respect to foreign relative prices $\left(p_{N t}^{*}-p_{T t}^{*}\right)$ and then increases the real exchange rate. However, the increase of tradable production with respect to non-tradable production (Figure 12) -under unchanged factorsresults in a real exchange rate appreciation. The increase of tradable production increases the productivity in tradable sector with respect to non-tradable sector, which increases domestic relative prices $\left(p_{N t}-\right.$ $\left.p_{T t}\right)$ with respect to foreign relative prices $\left(p_{N t}^{*}-p_{T t}^{*}\right)$ and then decreases the real exchange rate.

\section{Coefficients of allocation $\boldsymbol{t}$ and $n$}

Increasing foreign capital stock (Figure 13 and Figure 14) with respect to domestic capital stock in tradable sector (in non-tradable sector) under unchanged other parameters, results in real exchange rate appreciation (depreciation). The increase of $1-t(1-n)$ increases the productivity of tradable sector 
(non-tradable sector), which decreases tradable prices (non-tradable prices) with respect to non-tradable prices (tradable prices). As a result, domestic relative prices increase (decrease) with respect to foreign relative prices, which decreases (increases) the real exchange rate.

Increasing the output elasticities of foreign factors (Figure 15 and Figure 16) with respect to the output elasticities of domestic factors in tradable sector (in non-tradable sector) results also in real exchange rate appreciation (depreciation). The increase of $1-\alpha(1-\beta)$ gives the same result as the increase of $1-t(1-n)$. Accordingly, foreign capital allocation and foreign factors contribution by sector are important for developing countries: the more foreign firms invest in tradable sector and foreign factors contribution increases in tradable sector, the more the real exchange rate appreciates.

\section{Risk premium $\rho$ and raising domestic wage level $W$}

Reducing risk premium and raising domestic wage level with respect to foreign wage level (Figure 17 and Figure 18) result in real exchange rate appreciation. However, their effect on real exchange rate is minor. Thus, when risk premium is reduced to zero and domestic wage level is raised to equalize foreign wage level, the marginal products of foreign capital and of foreign labor becomes equal to the marginal products of domestic capital and of domestic labor (which is compatible with more financial development, capital market liberalization and economic integration). As a result, given that the output elasticity of foreign factors in tradable sector is higher than in non-tradable sector $(1-\alpha>1-\beta)$, domestic relative prices increase with respect to foreign relative prices and then real exchange rate appreciates.

\section{CONCLUSION}

It's common to notice a real exchange rate appreciation during the period of economic transition and convergence. Morocco, as a small developing country, is in this situation and its real effective exchange rate shows a downward tendency from 2000 to 2017. This can be explained by the fact that developing countries tend to grow faster than developed countries (catching up effect). We refer to BalassaSamuelson effect to model the link between relative prices (domestic and foreign) and relative productivities (domestic and foreign).

To examine the Moroccan case, we model the real effective exchange rate as a result of relative productivity differentials between tradable goods sector and non-tradable goods sector. Furthermore, we developed a specific Balassa-Samuelson model based on the theoretical framework of Balassa (1964) and Samuelson (1964) and on some recent modeling frameworks. Accordingly, we consider two coupled economies formed of a small open economy and of a developed economy -with two sectors- to explain how domestic and foreign variables affect the real effective exchange rate.

The results show that an increase in trade openness rate, in the weight of US dollar in Moroccan dirham's quoting basket currencies, in tradable production, in foreign tradable capital stock, in foreign tradable factors' output elasticity and in domestic wage level results in an increase in tradable sector productivity with respect to non-tradable sector productivity. Increasing these parameters and variables means more trade openness with the rest of the world (especially with United States) and more financial liberalization in tradable sector (i.e. more foreign capital flows to private sector). Thus, the increase in domestic relative productivity increases the domestic relative prices with respect to the foreign relative prices, which appreciates the real effective exchange rate.

However, an increase in domestic labor output elasticity, in labor transfers and capital transfers to tradable sector, in foreign non-tradable capital stock and in foreign non-tradable factors' output elasticity results in a decrease in tradable sector productivity with respect to non-tradable sector productivity. Increasing these parameters means more skilled domestic labor with less domestic factors in non-tradable 
sector and more financial liberalization in non-tradable sector (i.e. more foreign capital flows to public sector). Thus, the decrease in domestic relative productivities decreases the domestic relative prices with respect to foreign relative prices, which increase in the real exchange rate.

Definitively, the results indicate the extent to which liberalization policy affects the real effective exchange rate and then the external economic competitiveness of Morocco. The real effective exchange rate appreciation and depreciation are highly dependent on the exchange rate regime. Thus, allowing nominal exchange rate to float will reduce real exchange rate adjustments .Indeed, the model doesn't take into consideration the possible reform of the current fixed exchange regime. Analyzing Balassa-Samuelson effect under more flexible exchange rate regime and adopting a dynamic modeling may improve our understanding of the links.

\section{REFERENCES}

Balassa, B. (1964). The purchasing-power parity doctrine: a reappraisal. Journal of political Economy, 72(6), 584-596.

Barrera, N., Celasun, O., Estevão, M., Keim, G., Maechler, A., Mills, P., \& Bhatia, A. (2009). United States: Selected Issues. IMF Country Report $\mathrm{N}^{\circ}$ 09/229, p. 12.

Baumol, W. J., \& Bowen, W. G. (1966). Performing arts: the economic dilemma (New York: Twentieth Century Fund). The Performing Arts: The Economic Dilemma-1966.

Canzoneri, M. B., Cumby, R. E., \& Diba, B. (1999). Relative labor productivity and the real exchange rate in the long run: evidence for a panel of OECD countries. Journal of international economics, 47(2), 245-266.

Choudhri, E. U., \& Khan, M. S. (2005). Real exchange rates in developing countries: are Balassa-Samuelson effects present?. IMF Staff Papers, 52(3), 387-409.

Čihák, M., \& Holub, T. (2003). Price Convergence: What Can the Balassa-Samuelson Model Tell Us?. Czech Journal of Economics and Finance, 53(7)-8, 334.

Coudert, V. (2004). Measuring the Balassa-Samuelson effect for the countries of central and Eastern Europe?. Banque de France, Bulletin DIGEST, February, № 122.

Damodaran, A. (2016). Country Risk: Determinants, Measures and Implications. New York University - Stern School of Business, July, the 2016 Edition.

Devereux, M. (2001). Monetary policy, exchange rate flexibility, and exchange rate pass-through. Revisiting the Case for Flexible Exchange Rates, 47-82.

Devereux, M. B. (2003). A macroeconomic analysis of EU accession under alternative monetary policies. Journal of Common Market Studies, 41(5), 941-964.

Devereux, M. B., Lane, P. R., \& Xu, J. (2006). Exchange rates and monetary policy in emerging market economies. The Economic Journal, 116(511), 478-506.

Dixit, A. K., \& Stiglitz, J. E. (1977). Monopolistic competition and optimum product diversity. The American economic review, 67(3), 297-308.

Eken, S., Sarr, A., Bouhga-Hagbe, J., \& Vandenbussche, J. (2005). Morocco: Selected Issues. IMF Country Report $\mathrm{N}^{\circ} 05 / 419$.

Ezzahid, E., \& Maouhoub, B. (2014). Capital account liberalization and exchange rate flexibility: Scenarios for the Moroccan case. Economics Discussion Papers, Economics Ejournal, (No. 2014-18).

Ezzahid, E., \& Maouhoub, B. (2020). Capital account liberalization in morocco: is it compatible with fixed or flexible exchange rate regime?. Journal of Central Banking Theory and Practice, 9(1), 185-218.

Froot, K. A., \& Rogoff, K. (1992). Government consumption and the real exchange rate: The empirical evidence. Harvard University, June 1992.

Froot, K. A., \& Rogoff, K. (1995). Perspectives on PPP and long-run real exchange rates. Handbook of international economics, 3, 1647-1688.

Gali, J., \& Monacelli, T. (2005). Monetary policy and exchange rate volatility in a small open economy. The Review of Economic Studies, 72(3), 707-734.

García-Solanes, J., \& Torrejón-Flores, F. (2009). The Balassa-Samuelson hypothesis in developed countries and emerging market economies: different outcomes explained. Economics: The Open-Access, Open-Assessment EJournal, 3, 2. 
Pill, H., \& Pradhan, M. (1997). Financial liberalization in Africa and Asia. Finance and Development, 34, 7-10.

Irandoust, M., \& Sjöö, B. (2002). Productivity and Real Exchange Rates: Some Empirical Examples. Journal of Economic Integration, 527-553.

Khan, M. S., \& Khan, A. H. (1998). Capital Flows to Developing Countries: Blessing or Curse?[with Comments]. The Pakistan Development Review, 37(4), 125-151.

Krumm, K. L. (1993). A medium-term framework for analyzing the real exchange rate, with applications to the Philippines and Tanzania. The World Bank Economic Review, 7(2), 219-245.

Mark, N. C., \& Choi, D. Y. (1997). Real exchange-rate prediction over long horizons. Journal of International Economics, 43(1-2), 29-60.

Maris, M. (2019). Structural and productivity shift of industries in Slovakia and Czech Republic: A comparative study. Journal of International Studies, 12(1), 313-323.

Ravenna, F., \& Natalucci, F. M. (2008). Monetary policy choices in emerging market economies: The case of high productivity growth. Journal of Money, Credit and Banking, 40(2-3), 243-271.

Obstfeld, M., \& Rogoff, K. (2000). New directions for stochastic open economy models. Journal of international economics, 50(1), 117-153.

Roeger, W. (2006). The Production Function Approach to Calculating Potential Growth and Output Gaps Estimates for EU Member States and the US. EU-Commission, DG ECFIN, April, p. 5.

Samuelson, P. A. (1964). Theoretical notes on trade problems. The review of economics and statistics, 46(2), 147-154.

Sanusi, K. A., Meyer, D. F., \& Hassan, A. S. (2019). An investigation of the determinants of foreign exchange reserves in Southern African countries. Journal of International Studies, 12(2), 201-212;

Strýčková, L. (2017). The practice of capital structure choice in the Czech Republic: A comparative study based on the global data. Journal of International Studies, 10(2), 185-203.

Unayama, T. (2003). Product Variety and Real Exchange Rates: The Balassa-Samuelson Model Reconsidered. Journal of Economics, 79(1), 41-60. 


\section{APPENDIX}

\section{Figures}

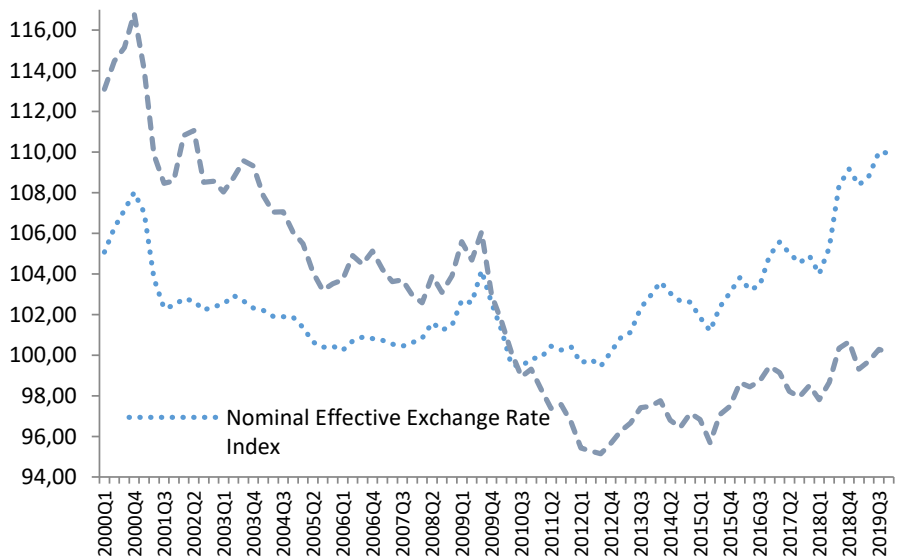

Figure 1. Nominal and Real effective exchange rate indexes in Morocco (Base 2010=100), Source: IMF dataset

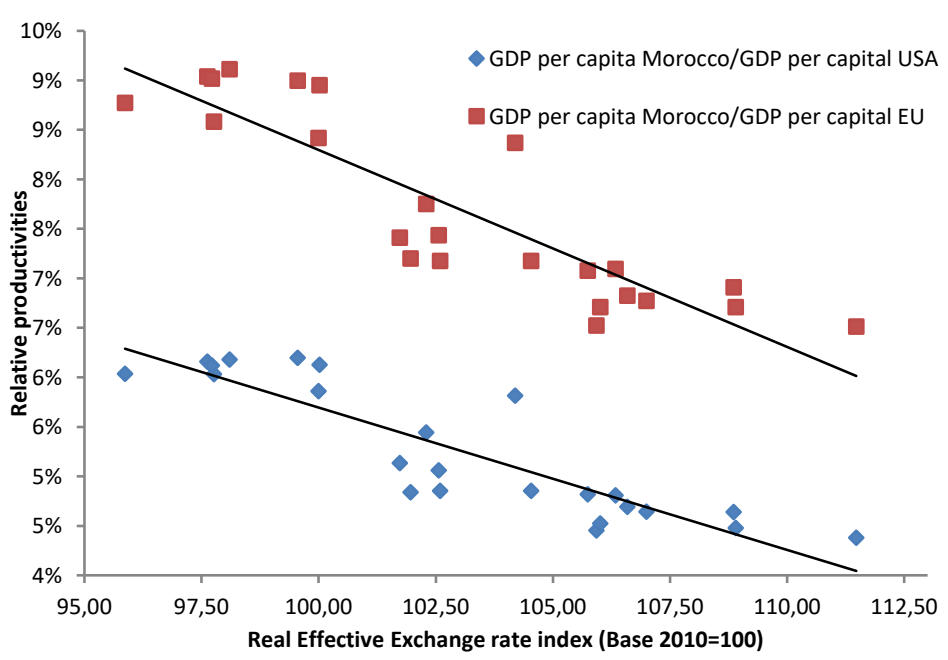

Figure 3. Real effective exchange rate index and relative productivities (GDP per capital, US $\$$ constant Base $2010=100$ ). Source: WB dataset

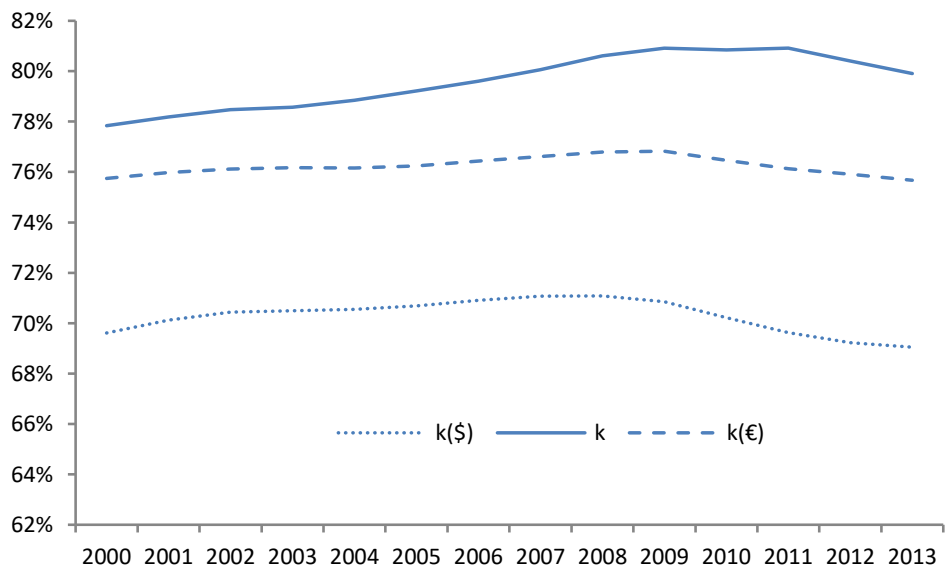

Figure 5. Coefficients of allocation $\kappa, \kappa^{€}$ and $\kappa^{\$}$. Source: IMF, Investment and Capital Stock Dataset. Authors' calculation.

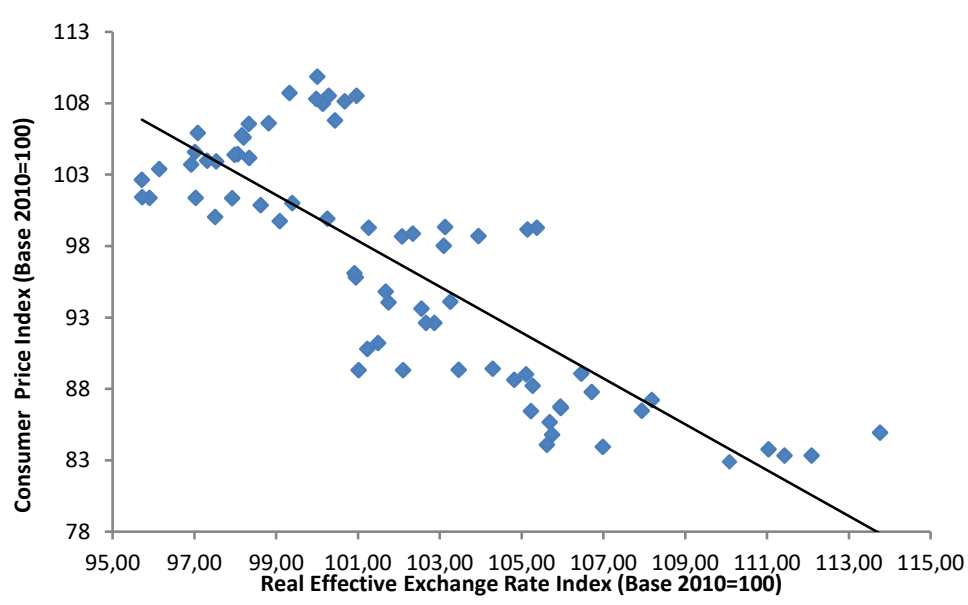

Figure 2. Real effective exchange rate index and Price consumer index in Morocco (Base 2010=100), Source: IMF dataset

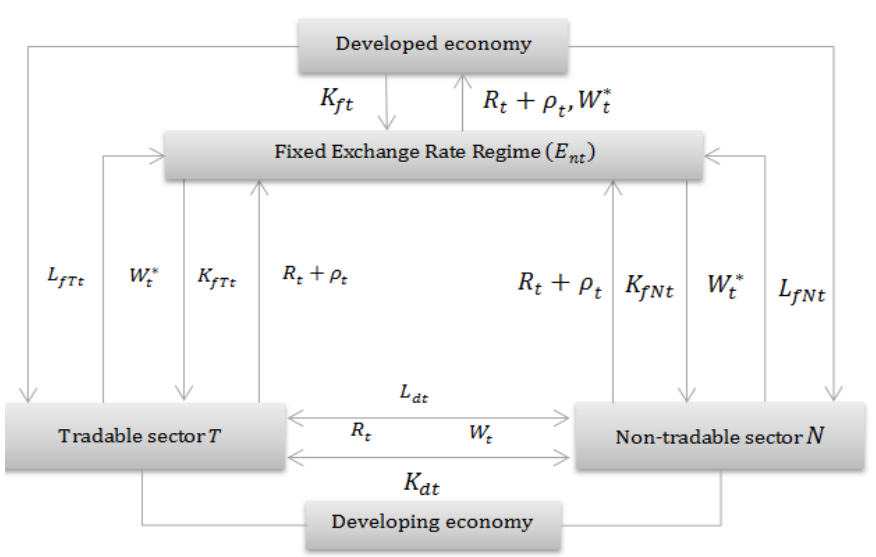

Figure 4. Model interactions between the developing economy and the developed economy. Authors' design

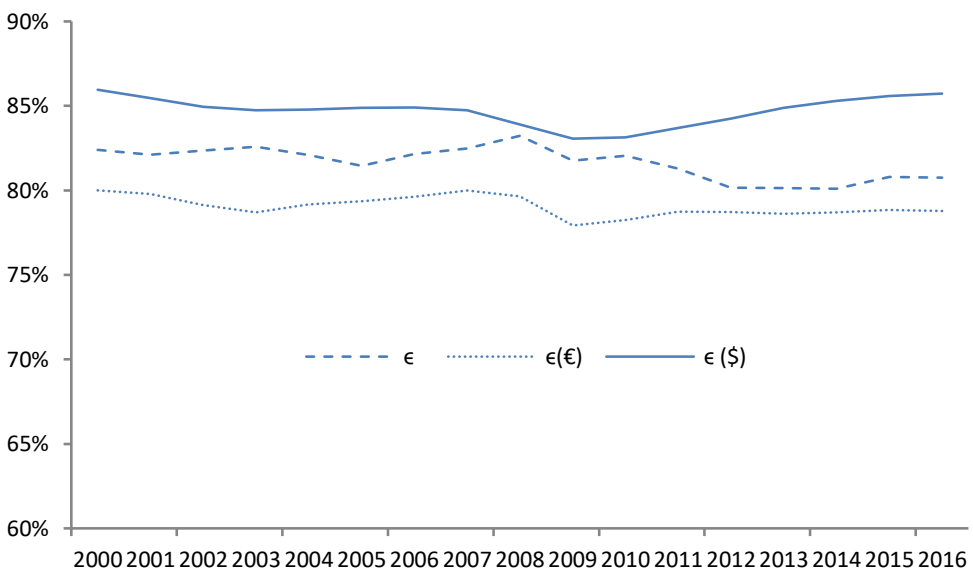

Figure 6. Coefficients of allocation $\epsilon, \epsilon^{\$}$ and $\epsilon^{\$}$. Source: The World Bank Dataset. Authors' calculation. 


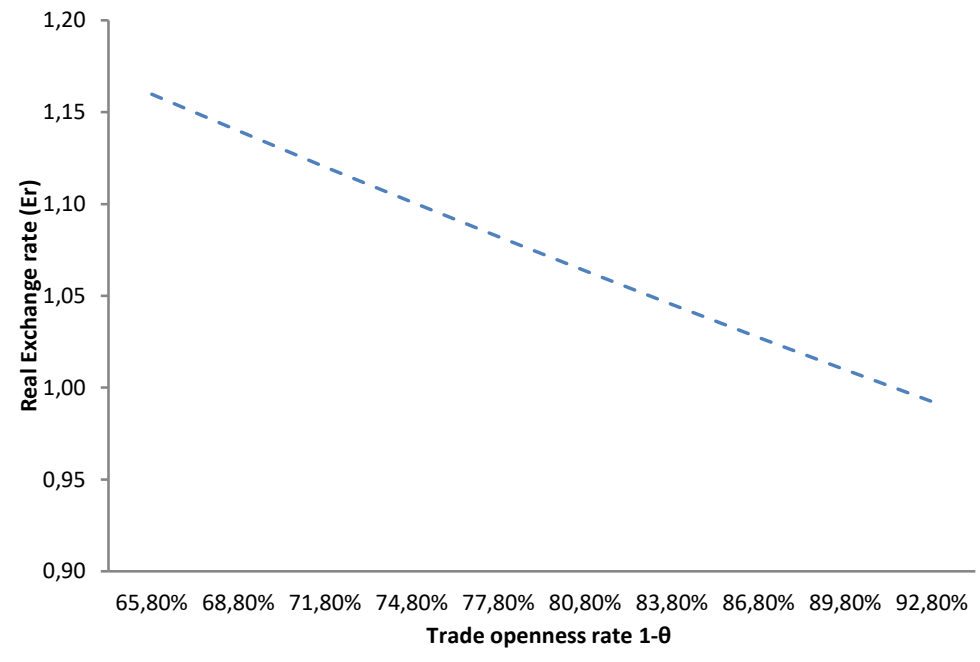

Figure 7. Real exchange rate and trade openness rate. Authors' calculation.

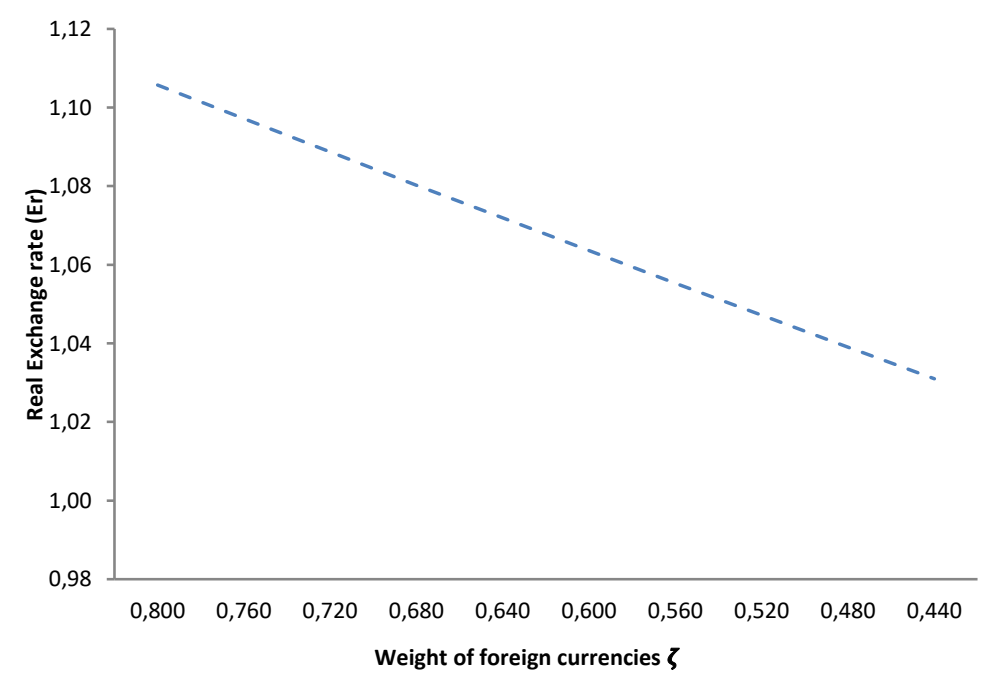

Figure 9. Real exchange rate and Weight of foreign currencies. Authors'

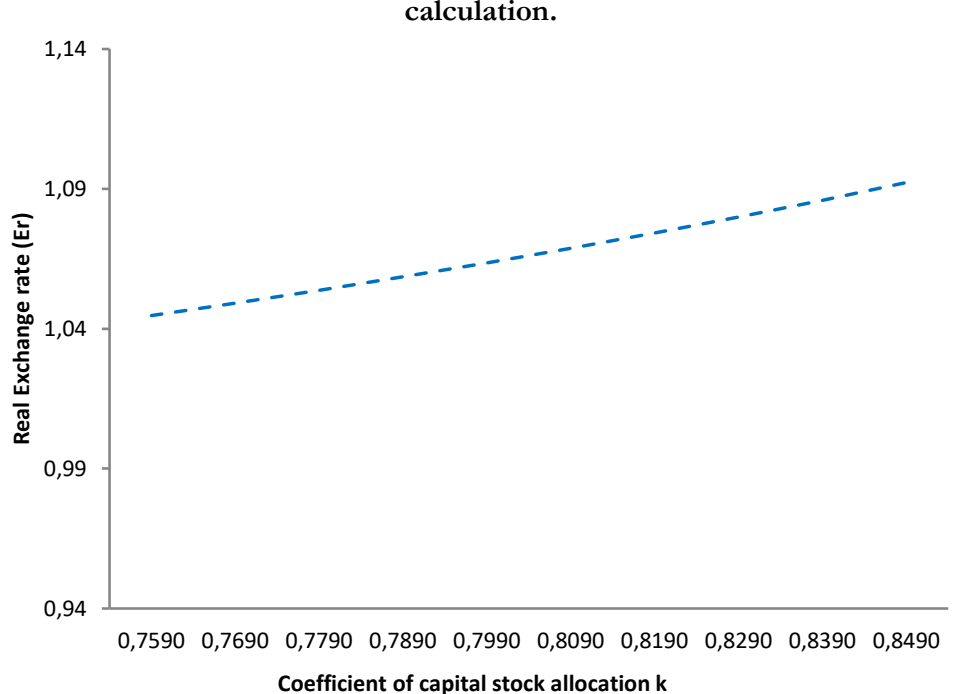

Figure 11. Real exchange rate and capital transfers. Authors' calculation.

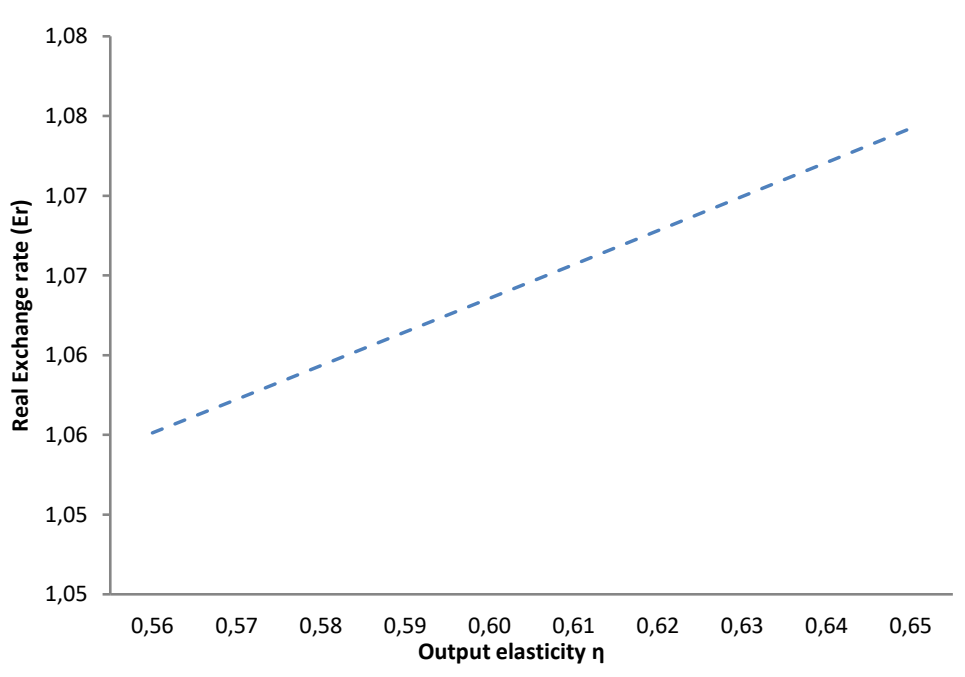

Figure 8. Real exchange rate and output elasticity $\eta$. Authors' calculation.

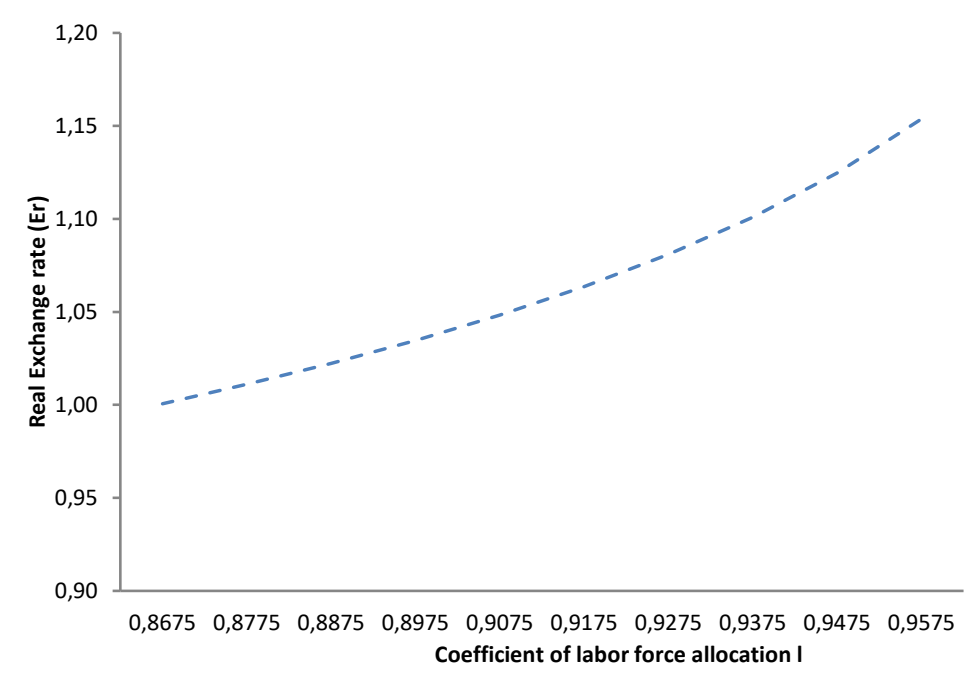

Figure 10. Real exchange rate and labor force transfers. Authors' calculation.

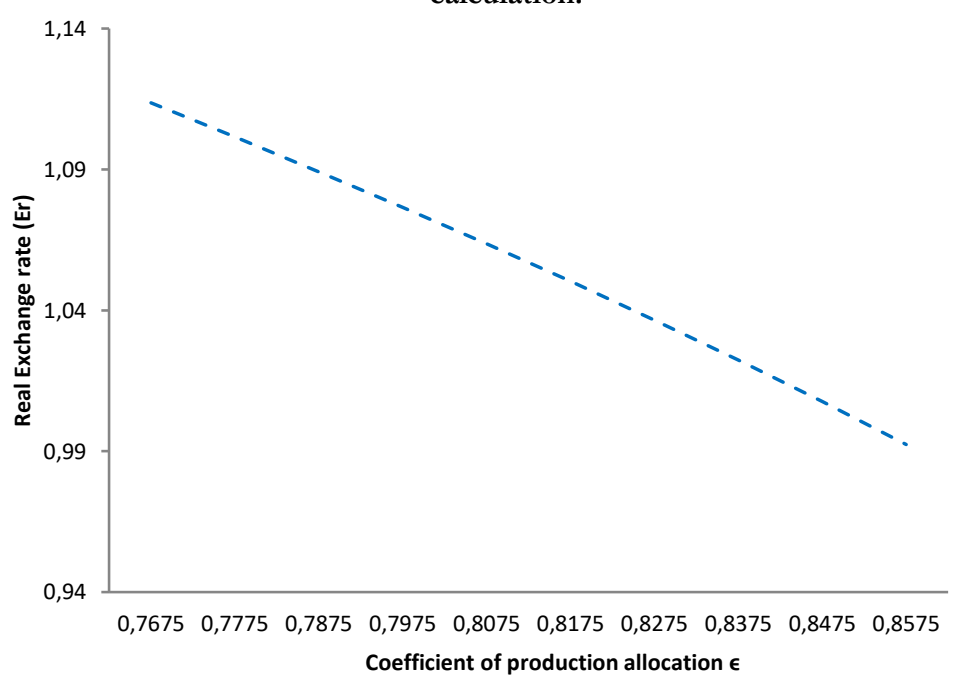

Figure 12. Real exchange rate and production allocation. Authors' calculation. 


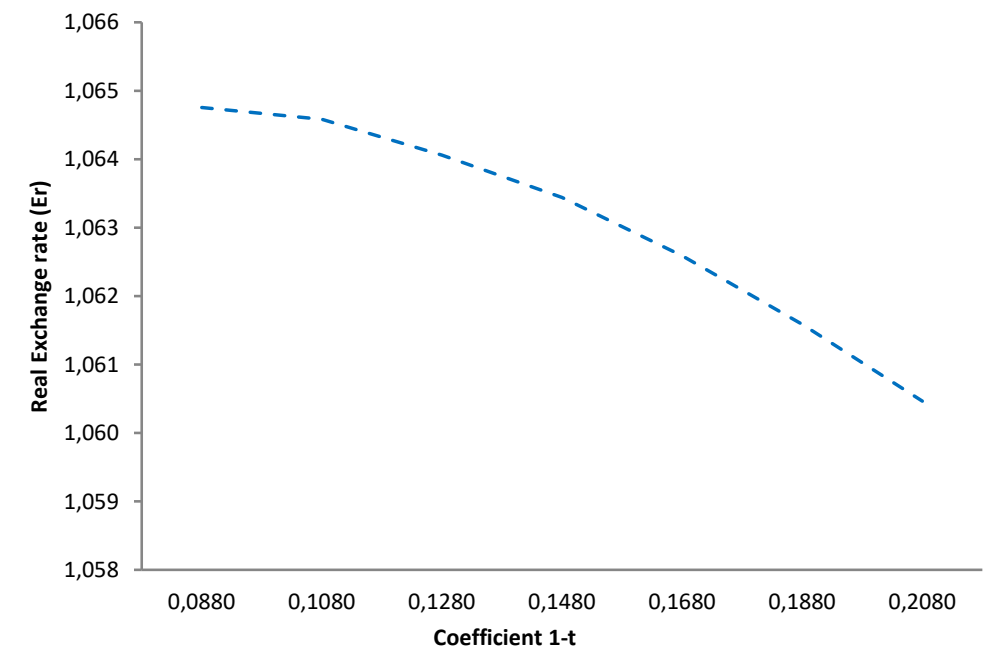

Figure 13. Real exchange rate and foreign capital stock in tradable sector. Authors' calculation.

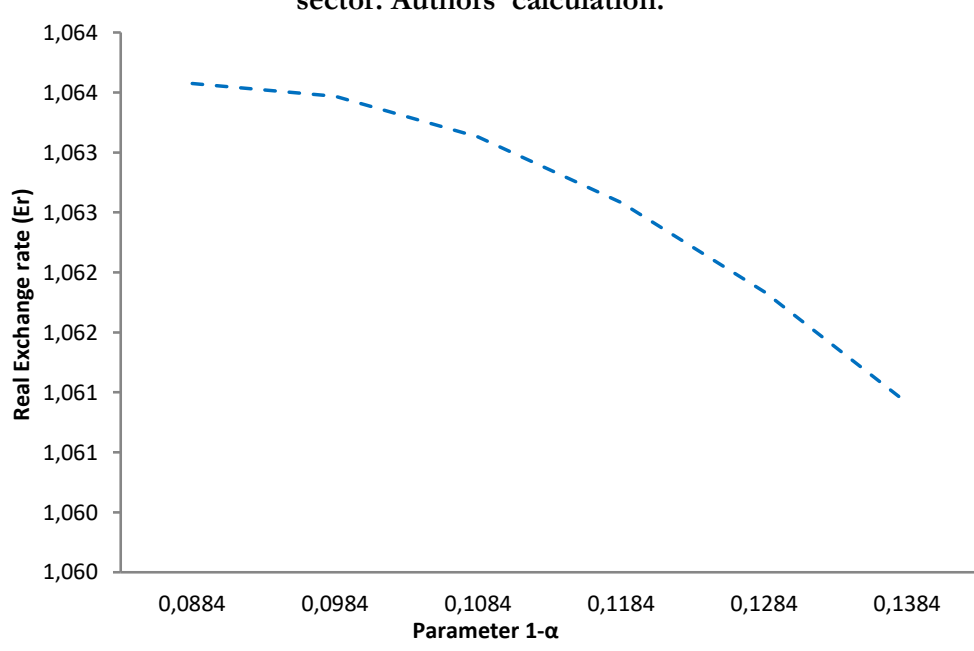

Figure 15. Real exchange rate and foreign factors' output elasticity in tradable sector. Authors' calculation.

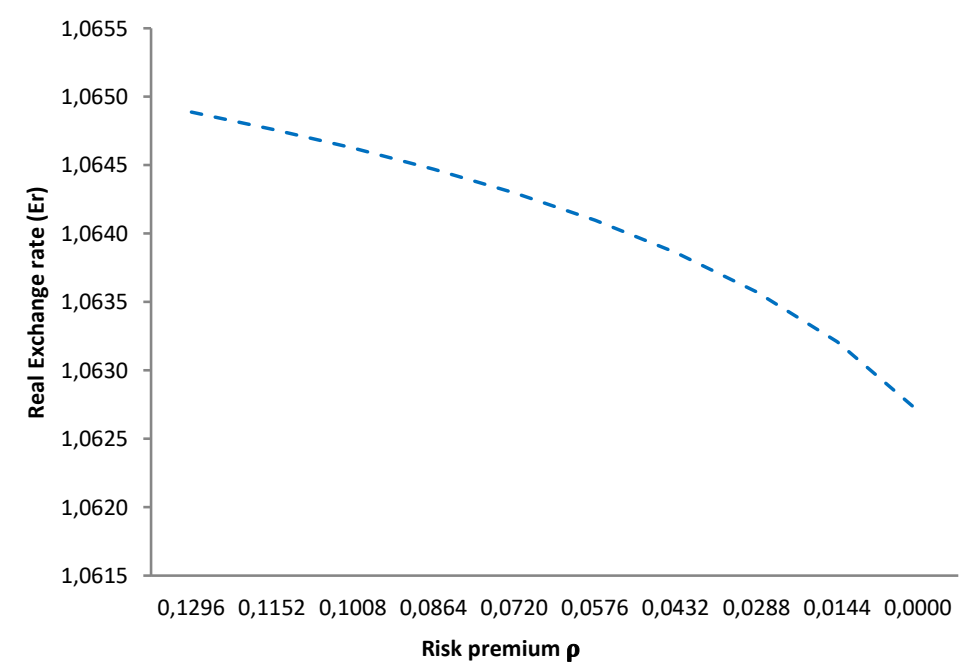

Figure 17. Real exchange rate and risk premium. Authors' calculation.

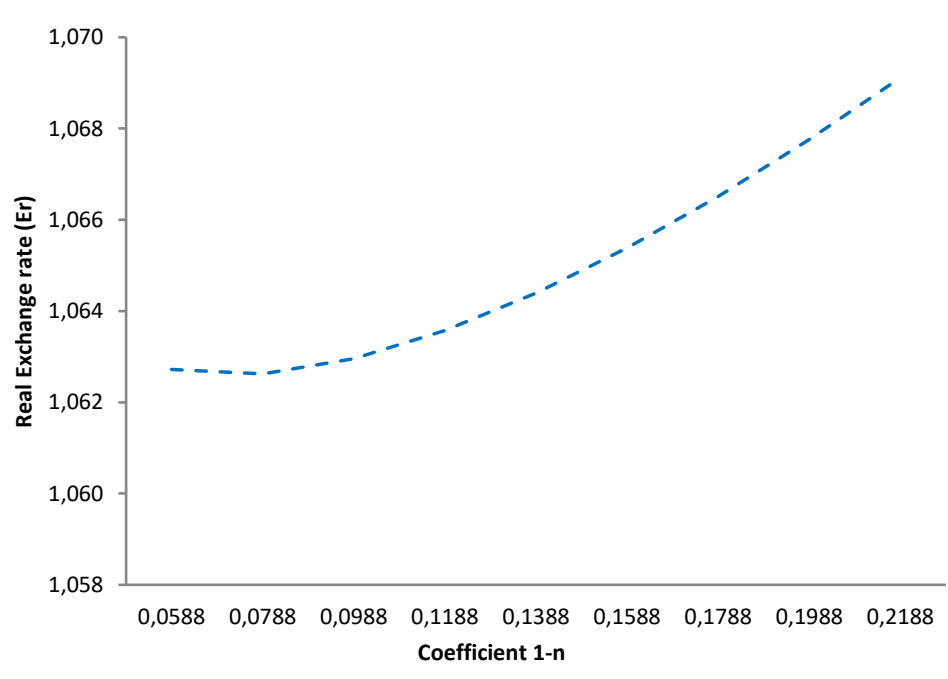

Figure 14. Real exchange rate and foreign capital stock in non-tradable

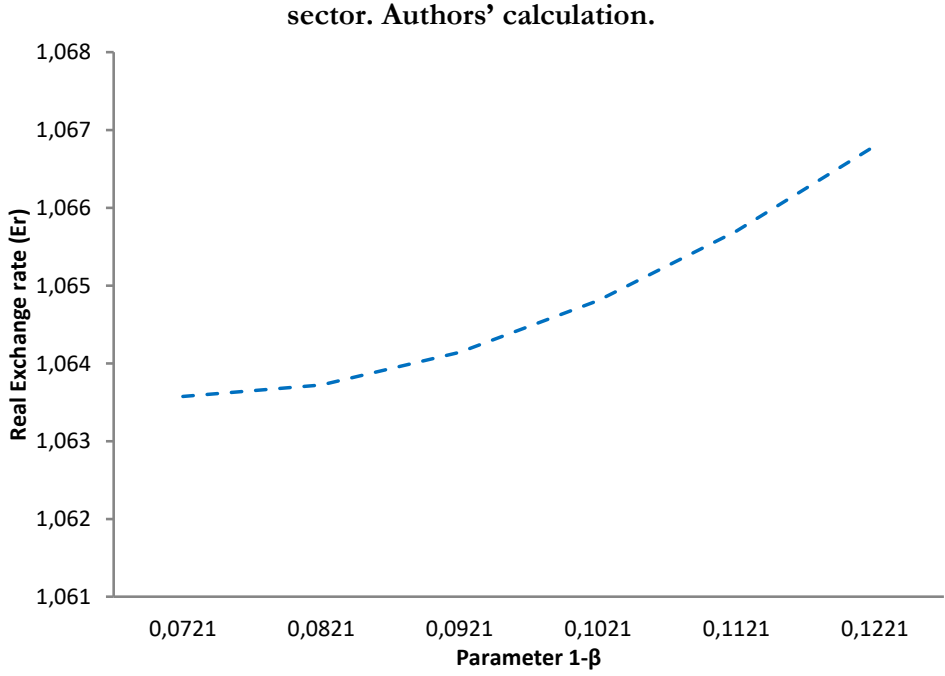

Figure 16. Real exchange rate and foreign factors' output elasticity in non-tradable sector. Authors' calculation.

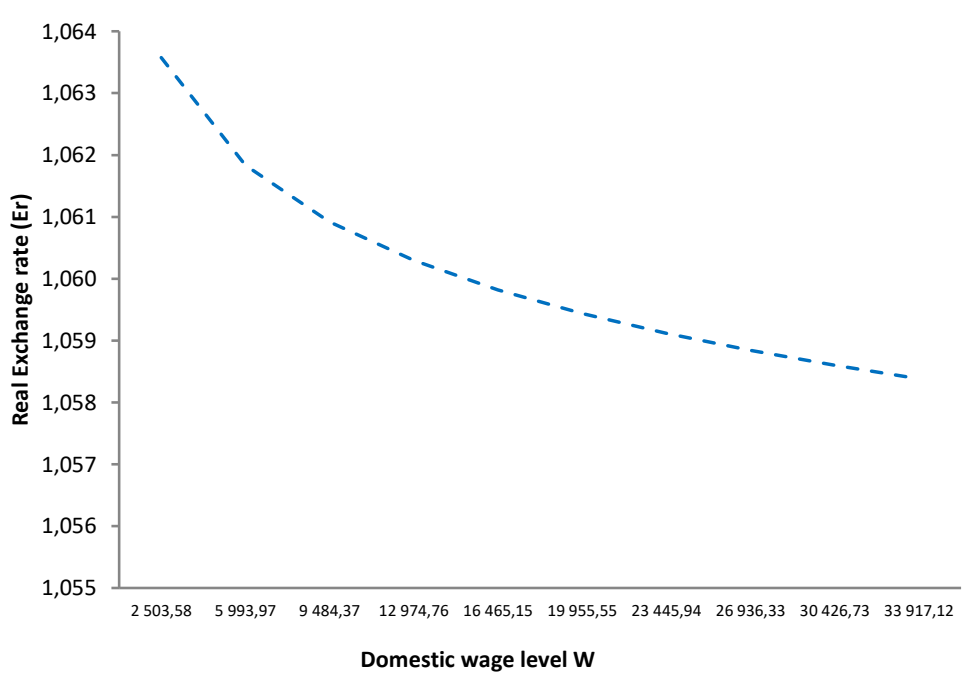

Figure 18. Real exchange rate and domestic wage level. Authors' calculation. 


\section{Tables}

Table 1

Trade openness rate in Morocco, European Union and United States. Source: Wold Bank dataset (2017). Authors' calculation

\begin{tabular}{|l|c|c|c|c|}
\hline \multicolumn{1}{|c|}{ Countries } & $\begin{array}{c}\text { Imports of goods and } \\
\text { services (BoP, current } \\
\text { US\$) }\end{array}$ & $\begin{array}{c}\text { Exports of goods and } \\
\text { services (BoP, current } \\
\text { US\$) }\end{array}$ & GDP (current US\$) & $\begin{array}{c}\text { Trade Openness (\% of } \\
\text { GDP) }\end{array}$ \\
\hline Morocco & $4.94 \mathrm{E}+10$ & $3.87 \mathrm{E}+10$ & $1.09 \mathrm{E}+11$ & $80.80 \%$ \\
\hline European Union & $7.30 \mathrm{E}+12$ & $7.95 \mathrm{E}+12$ & $1.73 \mathrm{E}+13$ & $88.25 \%$ \\
\hline United States & $2.90 \mathrm{E}+12$ & $2.33 \mathrm{E}+12$ & $1.94 \mathrm{E}+13$ & $26.98 \%$ \\
\hline
\end{tabular}

Labor and capital output elasticities

\begin{tabular}{|l|c|c|l|}
\hline \multicolumn{1}{|c|}{ Countries } & Labor output elasticity & Capital output elasticity & \multicolumn{1}{c|}{ Sources } \\
\hline Morocco & $\eta=0.60$ & $1-\eta=0.40$ & Eken, S. et al. (2005, pp. 14-15) \\
\hline European Union & $\eta^{€}=0.63$ & $1-\eta^{€}=0.37$ & Roeger, W. (2006, p. 4) \\
\hline United States & $\eta^{\$}=0.70$ & $1-\eta^{\$}=0.30$ & Barrera, N. et al. (2009, p. 12) \\
\hline
\end{tabular}

Weighted average measured by Adjusted net national income per capital (in current US\$). Source: World Bank Dataset (2015)

\begin{tabular}{|l|r|}
\hline \multicolumn{1}{|c|}{ Countries } & Adjusted net national income per capita (current US \$) \\
\hline Morocco & $2,503.58$ \\
\hline European Union & $26,551.84$ \\
\hline United-States & $48,967.22$ \\
\hline
\end{tabular}

Criteria and ratios for distinguishing between tradable sector and non-tradable sector, and for calculating of the coefficients of allocation

\begin{tabular}{|l|c|c|}
\hline Factors & Coefficient of allocation in Tradable sector & Coefficient of allocation in Non-tradable sector \\
\hline Labor & $l=\frac{\text { Labor force in private sector }}{\text { Total labor force }}$ & $1-l=\frac{\text { Labor force in public sector }}{\text { Total labor force }}$ \\
\hline Capital & $\kappa=\frac{\text { Capital stock in private sector }}{\text { Capital stock }}$ & $1-\kappa=\frac{\text { Capital stock in public sector }}{\text { Capital stock }}$ \\
\hline Production & $\epsilon=1-\frac{\text { Governement final consumption expenditure }}{\text { Cross domestic product }}$ & $1-\epsilon=\frac{\text { Governement final consumption expenditure }}{\text { Cross domestic product }}$ \\
\hline
\end{tabular}


Estimated coefficients of allocation $l, \kappa$ and $\epsilon\left(\mathrm{I}^{*}, \kappa^{*}\right.$ and $\left.\epsilon^{*}\right)$. Authors' calculation

\begin{tabular}{|c|c|c|c|c|c|}
\hline Factors & Country & $\begin{array}{l}\text { Coefficient of } \\
\text { allocation in } \\
\text { Tradable sector }\end{array}$ & $\begin{array}{l}\text { Coefficient of } \\
\text { allocation in Non- } \\
\text { tradable sector }\end{array}$ & Source & Available data \\
\hline \multirow{3}{*}{ Labor } & Morocco & 0.9175 & 0.0825 & \multirow{3}{*}{$\begin{array}{l}\text { International Labor } \\
\text { Organization Dataset }\end{array}$} & \multirow{3}{*}{2008} \\
\hline & European Union & 0.8776 & 0.1224 & & \\
\hline & United-States & 0.8417 & 0.1583 & & \\
\hline \multirow{3}{*}{ Capital } & Morocco & 0.7990 & 0.2010 & \multirow{3}{*}{$\begin{array}{c}\text { International } \\
\text { Monetary Fund, } \\
\text { Investment and } \\
\text { Capital Stock Dataset }\end{array}$} & \multirow{3}{*}{2013} \\
\hline & European Union & 0.7567 & 0.2433 & & \\
\hline & United-States & 0.6905 & 0.3095 & & \\
\hline \multirow{3}{*}{ Production } & Morocco & 0.8075 & 0.1925 & \multirow{3}{*}{ World Bank Dataset } & \multirow{3}{*}{2016} \\
\hline & European Union & 0.7877 & 0.2123 & & \\
\hline & United-States & 0.8573 & 0.1427 & & \\
\hline
\end{tabular}

Table 6

Decomposition of foreign direct investment stock by sector. Source: Office de Change (2014)

\begin{tabular}{|l|c|c|}
\hline Criteria & $\begin{array}{c}\text { \% in real estate sector } \\
\text { (Non-tradable sector) }\end{array}$ & $\begin{array}{c}\text { \% in all other sectors } \\
\text { (Tradable sector) }\end{array}$ \\
\hline Foreign direct investment stock & $16.90 \%$ & $83.10 \%$ \\
\hline
\end{tabular}

Table 7

Domestic capital stock and foreign capital stock in private and public sectors. Authors' calculation

\begin{tabular}{|l|c|c|c|}
\hline \multirow{2}{*}{ (In Billions of constant US\$, Base 100= 2005) } & Sector & Tradable sector & $\begin{array}{c}\text { Non-tradable } \\
\text { sector }\end{array}$ \\
\cline { 2 - 4 } & Allocation & $\boldsymbol{\kappa}=\mathbf{0 . 7 9 9 0}$ & $\mathbf{1 - \boldsymbol { \kappa } = \mathbf { 0 . 2 0 1 0 }}$ \\
\hline Total capital stock (1)= (2)+ (3) & 348.07 & $\mathbf{2 7 8 . 1 0}$ & $\mathbf{6 9 . 9 6}$ \\
\hline \multirow{2}{*}{ Domestic capital stock (2) } & 332.02 & 264.77 & 67.25 \\
\hline \multirow{2}{*}{ Foreign capital stock (3) } & & $t=0.9520$ & $n=0.9612$ \\
\hline
\end{tabular}

